\title{
PERAN PENYULUH AGAMA ISLAM \\ DALAM PENCEGAHAN DAN PENYELESAIAN KONFLIK UMAT BERAGAMA DI KECAMATAN SEWON
}

\author{
Wahyu Sinangsih \\ Program Studi Komunikasi dan Konseling Islam \\ Program Pasca Sarjana \\ Universitas Muhammadiyah Yogyakarta \\ E-mail: wahyusinangsih@gmail.com
}

\begin{abstract}
Abstrak
Penelitian ini bertujuan untuk meneliti peran penyuluh agam Islam dalam pencegahan dan penyelesaian konflik umat beragama di kecamatan Sewon. Jenis penelitian ini adalah penelitian lapangan dengan menggunakan pendekatan kualitatif. Lokasi penelitian adalah Dukuh Saman kecamatan Sewon Kabupaten Bantul Daerah Istimewa Yogyakarta. Hasil penelitian ini: (1) Konflik-konflik yang ada di Kecamatan Sewon ada empat konflik pemahaman NU dan Muhammadiyah, konflik tempat peribadatan di Dongkelan, konflik Gereja St Martinus di Gandok dan konflik Gereja Kristen Baptis di Saman, (2) Peran penyuluh agama Islam dalam pencegahan dan penyelesaian umat beragama dalam internal umat Islam melalui ceramah, dan dialog sedangkan eksternal umat beragama yaitu melalui ceramah, dialog antar umat beragama, sosialisasi pendirian tempat ibadah, kegiatan bersama dan pendampingan jamaah, (3) Faktor yang mendukung adalah kesadaran agama, dari eksternal pemahaman agama yang baik dan dukungan pemerintah melalui pembentukan FKUB sampai tingkat Kecamatan. Factor penghambat dari internal adalah ego golongan, pemahaman agama yang kurang dan ekonomi, dari ekternal adalah fanatic agama yang buta dan kurangnya pemetaan dakwah terutama daerah rawan.
\end{abstract}

Kata kunci: peran penyuluh agama islam, konflik umat beragama

\begin{abstract}
This study aims to examine the role of religious counselors of Islam in the prevention and resolution of religious conflicts in the district of Sewon. This type of research is field research using qualitative approach. The location of the research is Dukuh Saman, Sewon district, Bantul regency, Yogyakarta Special Region. The results of this study are: (1) Conflicts in Sewon Sub-district there are four conflicts of understanding between NU and Muhammadiyah, conflicts of worship in Dongkelan, St Martinus Church conflict in Gandok and conflict of Baptist Christian Church in Saman, (2) in the prevention and resolution of religious communities within the Muslim community through lectures, and dialogue while external religious communities are through lectures, inter-religious dialogue, socialization of places of worship, joint activities and mentoring, (3) Supportive factors are religious awareness, external understanding of good religion and government support through the establishment of FKUB to the District level. Internal inhibiting factors are group ego, lack of understanding of religion and economy, from external is fanatic religion blind and lack of mapping of preaching especially vulnerable areas.

Keywords: the role of religious counselors of Islam, religious conflict
\end{abstract}

\section{Info Artikel}

Diterima Agustus 2017, disetujui September 2017, diterbitkan Desember 2017

Dipublikasikan Oleh: Program Studi Bimbingan dan Konseling 
PENDAHULUAN

Penyuluh Agama Islam mempunyai peran sebagai pembimbing umat dengan penuh tanggung jawab, membawa masyarakat kepada kehidupan yang aman dan sejahtera.Penyuluh Agama menjadi tempat bertanya dan mengadu bagi masyarakat untuk dapat memecahkan persoalan dan menyelesaikan dengan nasihatnasihatnya. Dengan demikian peran penyuluh sangat strategis di dalam kehidupan bermasyarakat dan berbangsa Indonesia.

Penyuluh di dalam masyarakat selain sebagai tempat curahan hati juga sebagai konselor dan motivator.Motivator terutama sebagai pendorong masyarakat untuk berpartisipasi aktif dalam pembangunan.Selain itu penyuluh juga berperan ikut serta mengatasi hambatan yang membangun jalannya pembangunan, khususnya mengatasi dampak negatif.Penyuluh agama sebagai pemuka agama selalu membimbing, mengayomi, dan menggerakkan masyarakat untuk berbuat baik dan menjauhi perbuatan yang terlarang, mengajak kepada sesuatu yang menjadi keperluan masyarakatnya dalam membina wilayahnya baik untuk keperluan sarana kemasyarakatan maupun peribadatan.

Penyuluh adalah Pegawai Negeri Sipil yang diberikan tugas, tanggung jawab dan wewenang secara penuh oleh pejabat yang berwenang untuk melakukan bimbingan keagamaan dan penyuluhan pembangunan melalui bahasa agama .Di dalam penjabarannya Penyuluh mempunyai tugas bimbingan pengamalan penyuluhan, menyampaikan gagasan pembangunan dan meningkatkan kerukunan hidup beragama.

Tugas maupun peran Penyuluh Agama tersebut jika dapat dilakukan dengan baik dapat membantu menjaga keutuhan bangsa Indonesia sebagaimana semboyan bangsa kita yaitu Bhinneka Tunggal Ika, artinya berbeda-beda tetapi tetap satu jua. Sebagaimana Allah SWT di dalam Al Qur'an yaitu Surat Al Hujurat ayat 13 yang artinya

"Wahai manusia, sungguh Kami telah menciptakan kamu dari seorang lakilaki dan seorang perempuan, kemudian Kami jadikan kamuberbangsa-bangsa dan bersukusuku agar kamu saling kenal mengenal, Sungguh yang paling mulia disisi Allah ialah orang yang paling bertaqwa diantara kalian. Sungguh Allah Maha Mengetahui, Maha Teliti".

Dari ayat tersebut kalau ditelusuri dalam ajaran agama Islam adalah perlunya menjalin persaudaraan antar sesama umat manusia, karena walau diciptakan berbangsa kita disuruh saling mengenal.Tetapi hal yang mempengaruhi timbulnya perbedaan pandangan apalagi perbedaan paham ketuhanan manusia yang 
tajam.Persoalannya tidak hanya sekitar perbedaan dalam menafsirkan teks kitab suci, tetapi berhubungan dengan kondisi sosiokultural dan historis .

Secara geografis negeri Indonesia terbentang 13.000 lebih pulau, berpenduduk 220 juta orang (tahun 2001).Penduduk Indonesia mempunyai 370 suku bangsa dan lebih 67 bahasa daerah.Sejumlah etnis Melayu, Cina, Arab, India, dan Negrito berkumpul di dalam wadah Negara Kesatuan Republik Indonesia .

Berbagai macam agama yang ada di Indonesiatersebut tidak lepas dari sejarah bangsa Indonesia yang berkepulauan, sumber daya alam yang mempesona sehingga menjadi pusat perniagaan kala itu. Sebagai pusat perniagaan membuat masyarakat di penjuru dunia ingin singgah di Indonesia.Nenek moyang kita awalnya berkepercayaan animisme dan dinamisme kemudian masuk agamaagama yaitu Hindu, Budha, Islam kemudian Katholik dan Kristen.Perkembangan agama di Indonesia sangat pesat dan membutuhkan waktu yang cukup lama. Dalam waktu tersebut terjadilah interaksi agama yang satu dengan yang lain, yang kadang dapat menimbulkan gesekan atau konflik.

Konflik dari berbagai macam suku,etnis, ras maupun agama dapat terjadi karena dipengaruhi oleh beberapa faktor diantaranya kesalahpahaman ataupun ekonomi.Konflik agama di Indonesia tidak hanya terjadi dari eksternal agama tetapi bisa dari intern agama.Dari intern agama bisa terjadi adanya beberapa paham organisasi, aliran maupun sekte-sekte yang tumbuh subur di Negara kita.

Konflik yang pernah terjadi di Indonesia diantaranya adalah konflik Ambon, konflik Dayak-Madura. Konflik tersebut pada awalnya merupakan konflik karena faktor ekonomi akan tetapi berujung pada agama. Hal ini juga dapat terjadi di beberapa daerah yang ada di Indonesia, diantaranya Kabupaten Bantul Daerah Istimewa Yogyakarta.

Konflik yang sempat memanas sampai mendapatkan perhatian pemerintah pusat adalah konflik Gereja Saman, Bangunharjo, Kecamatan Sewon Kabupaten Bantul.Kecamatan Sewon terdiri dari empat kalurahan yaitu Panggungharjo, Pendowoharjo, Timbulharjo dan Bangunharjo. Penduduk Kecamatan Sewon berjumlah 86883 jiwa yang terdiri dari mayoritas muslim 83908 jiwa atau setara dengan $96,57 \%$, untuk masyarakat Kristen Protestan berjumlah 1131 atau 1,30 \%, masyarakat Katholik berjumlah 1591 atau $1,86 \%$, sedangkan masyarakat yang beragama Hindu ada 146 atau 0,16\% dan beragama Budha 107 jiwa atau $0,13 \%$.

Berbagai fakta yang terjadi di dalam masyarakat tersebut, ternyata Kecamatan Sewon rawan dengan konflik karena daerah batas kota dan 
penduduk yang majemuk. Di sisi lainpenyuluh belum berperan maksimal dalam pencegahan konflik umat beragama. Penyebab peran penyuluh belum maksimal ada beberapa faktor, diantaranya penyuluh kurang pemahaman tugas dan fungsinya.

\section{METODE PENELITIAN}

\section{Jenis dan Pendekatan Penelitian}

Jenis Penelitian tentang Peran Penyuluh Agama dalam pencegahan konflik umat beragama ini bersifat studi lapangan dan jenisnya penelitianini adalah studi kasus. Dalam penelitian ini akan menggunakan pendekatan kualitatif. Sedangkan bentuk penelitian yaitu deskriptif analitif. Lokasi Penelitian dan subjek penelitiantentang Peran Penyuluh Agama Islam dalam pencegahan dan penyelesaian konflik umat beragama dilakukan di Kecamatan Sewon Kabupaten Bantul.

Penentuan subjek penelitian dilakukan dengan purposive sampel atau seleksi berdasarkan kriteria (criterian basedselection). Adapun subjek penelitian meliputi: 1) Ka KUA Kecamatan Sewon, sebagai mitra penyuluh agama Islam di kecamatan,

2) Pegawai Kecamatan dengan kriteria, memiliki tugas yang berhubungan dengan konflik kerukunan umat beragama, 3) Pengurus FKUB, dengan kriteria pengurus inti yang mewakili kelima agama di Kecamatan Sewon, 4) Penyuluh Agama Islam dengan kriteria sebagai berikut, yang telah minimal 1 tahun menjadi penyuluh di kecamatan Sewon, 5) Tokoh agama dengan kriteria menjadi pengurus Lembaga Dakwah besar yaitu NU dan Muhammadiyah.

Teknik pengambilan subjek penelitian berikutnya akan digunakan snow ball atau teknik domino.

\section{Teknik pengumpulan Data}

Beberapa Teknik pengumpulan data yang digunakan dalam penelitian ini adalah

1. Observasi partisipasi, peneliti terlibat dengan kegiatan seharihari orang yang diamati atau yang digunakan dalam sumber data penelitian. Sambil melakukan pengamatan peneliti ikut melakukan apa saja yang dikerjakan sumber data dan ikut merasakan suka dukanya . Hal ini dilakukan karena peneliti juga seorang Penyuluh Agama.

2. Wawancara mendalam dilakukan kepada: a) Kepala KUA Sewon untuk mendapatkan data Kecamatan sewon dan kejadiankejadian konflik, b) Pegawai kecamatan, untuk mendapatkan data konflik, c) Penyuluh Agama, tehnis dalam upaya mengumpulkan data yang akurat untuk keperluan proses pemecahan masalah tertentu sesuai dengan data dengan tehnis tanya jawab secara lisan dan bertatap muka langsung 
3. Dokumentasi, untuk melengkapi data-data penelitian kualitatif diperlukan dokumen yang berupa catatan-catan, rapor benda-benda yang tertulis yang relevan dengan penelitian. Data dokumentasi dapat dibedakan beberapa jenis :

a) Catatan resmi (ofecia of formal record) misalnya jumlah konflik yang terjadi, b) Dokumendokumen ekpresif ( expressive documents) misalnya biografi, autobiografi, surat-surat pribadi, dan buku harian, c) Laporan media massa (mass media report). Instrumen yang digunakan dalam penelitian ini adalah pedoman wawancara dan pedoman pengamatan. Instrumen berdasarkan indikator-indikator yang mengacu pada keyakinan masyarakat, peran penyuluh dalam penanggulangan konflik umat bergaama di kecamatan Sewon. Pengujian validitas instrument dilakukan dengan crosscheck ke lapangan.

\section{Analisa data}

Analisa data yang saya gunakan adalah analisis kualitatif menurut Miler dan Hubermen. Teknik analisis data ini dengan tiga penguatan yaitu :

1. Reduksi data,Reduksi data merupakan proses pemilihan, pemusatan perhatian, pengabstraksian dan pentransformasian data kasar dari lapangan. Proses ini berlangsung selama penelitian dilakukan, mulai dari awal sampai akhir penelitian. Pada awal misalnya melalui langkah konsepttual, permasalahan, pendekatan pengumpulan data yang diperoleh. Selama pengumpulan data, misalnya membuat ringkasan, metode mencari tema-tema, menulis memo, dan lain-lain. Reduksi merupakan bagian dari analis bukan terpisah. Fungsinya untuk menajmkan, menggolonggolongkan, mengarahkan yang tidak perlu, dan mengorganisasi sehingga intterpretasi bisa ditarik. Dalam proses reduksi ini peneliti benar-benar mencari data yang valid. Ketika peneliti menyaksikan kebenaran data yang diperoleh akan dicek ulang dengan informan yang lain.

2. Penyajian data adalah sekumpulan informasi tersusun yang memberi kemungkinan untuk menarik kesimpulan dan pengambilan tindakan. Bentuk penyajian antara lain berupa teks naratif, matriks, grafik, jaringan, dan bagan.Tujuan nya dalah mempermudah membaca dan menarik kesimpulan. Oleh karena itu sajiannya harus tertata baik penyajian data merupakan bagian dari analisi, bahkan mencakup pula reduksi data dalam proses ini peneliti mengelompokkan hal-hal yang serupa menjadi kategori atau kelompok satu, kelompok dua, kelompok tiga dan seterusnya. Masing-masing kelompok tersebut 
menunjukkan tipologi terdiri atas sub bagian. Dalam hal ini peneliti juga melakukan display (penyajian) data secara sistematik, karena lebih mudah untuk dipahami interaksi antara bagianbagiannya dalam konteks yang utuh bukan sekmental atau frasmental terlepas satu dengan lainnya. Dalam proses data diklasifisikan berdasarkan tematema inti.

3. Menarik kesimpulan atau verifikasi. Penarikan kesimpulan adalah bagian dari satu kegiatan dari konfigurasi yang utuh.Kesimpulan-kesimpulan juga diverifikasi selama penelitian berlangsung.Makna-makna yang muncul dari data harus selalu diuji kebenarannya dan kesesuaiannya sehingga validitasinya terjamin. Dalam tahap ini, peneliti membuat rumusan komposisi yang terkait dengan prinsip logika, mengangkatnya sebagai temuan penelitian, kemudian dilanjutkan dengan pengjkajian yang berulangulang terhadap data yang ada, pengelompokan data yang terbentuk dan proposisi yang telah dirumuskan. Langkah selanjutnya yaitu melaporkan hasil penelitian lengkap dengan temuan baru yang berbeda dari temuan yang sudah ada. Dalam melakukan penarikan kesimpulan dan verifikasi tentang peran penyuluh Agama Islam dalam pencegahan dan penyelesaian konflik di

Kecamatan Sewon dilakukan
dengan peninjauan terhadap
penyajian data dan catatan di
lapangan melalui diskusi dengan
teman sejawat dan arahan
pembimbing.

\section{HASIL PENELITIAN}

\section{Gambaran Kecamatan Sewon}

Kecamatan Sewon terdiri dari empat kalurahan yaitu Panggungharjo, Pendowoharjo, Timbulharjo dan Bangunharjo. Penduduk Kecamatan Sewon berjumlah 86883 jiwa yang terdiri dari mayoritas muslim 83908 jiwa atau setara dengan $96,57 \%$, untuk masyarakat Kristen Protestan berjumlah 1131 atau $1,30 \%$, masyarakat Katholik berjumlah 1591 atau $1,86 \%$, sedangkan masyarakat yang beragama Hindu ada 146 atau 0,16\% dan beragama Budha 107 jiwa atau $0,13 \%$.

Kecamatan Sewon yang terletak batas kota, bagian selatan masih pedesaan sedangkan bagian utara masuk perkotaan. Hal tersebut membuat Kecamatan Sewon banyak diminati dengan banyaknya pendatang yang berbagai macam latar belakang baik pendidikan, ras, budaya maupun agama.Data tersebut dapat memberikan gambaran karena padatnya penduduk yang bermacammacam juga rawan dengan konflik, baik karena factor ekonomi, social dan agama. 


\section{Konflik Yang Pernah Terjadi}

Konflik yang pernah terjadi di Sewon yaitu 1) Pemahaman masrakat anatara NU dan Muhammadiyah, 2) Rumah tempat peribadatan di Dongkelan Panggungharjo Sewon, 3) Gereja St Martinus Gandok Bangunharjo Sewon, 4) Pendirian Gereja Kristen Baptis di Saman Bangunharjo Sewon. Dilihat dari macam-macam konflik terdapat konflik prinsip dan konflik.

Sedangkan dilihat dari subjek pelaku konflik terdapat konflik internal umat Islam dan Antar Umat Beragama, Untuk internal masih dalam taraf pedukuhan dan belum meluas. Konflik Antar Umat Beragama terjadi di Saman sebagai berikut

1. Keterlibatan penyuluh agama Islam dan masyarakat, Penyuluh agama Islam dalam hal ini saudara Yulianta, S.Ag mempunyai peran dengan memberikan informasi tentang sosialisasi pendirian tempat Ibadah. Selain itu penyuluh agama mengandeng FKUB kecamatan Sewon dan beberapa lintas sektoral untuk penyelesaian konflik umat beragama serta beberapa warga masyarakat

2. Kapan dan dimana, Penyelesaian melalui sosialisasi pendirian tempat Ibadah dan dialog antar umat beragama.Dialog atau mediasi dilakukan pada tanggal 21 Juli 2015 di Aula kecamatan Sewon yang dihadiri oleh camat Sewon Wintarto, pihak desa
Bangunharjo, Koramil IV/Sewon, Polsek dan tokoh masyarakat Bangunharjo Sewon. Kesepakatan terjadi yaitu penutupan dan pencopotan nama GBI selain itu pihak Gereja Baptis Kristen harus merampungkan ijin terlebih dahulu. Gerejea dijaga oleh petugas kemanan smentara waktu agar terhindar dari hal-hal yang tidak diinginka dari pihak masyarakat Zainal meyatakan menindaklanjuti keresahan warga karena tindakan pihak gereja yang memaksa tanda-tangan warga.

3. Bentuk penyelesaian, bentuk penyelesaian konflik umat beragama di kecamatan Sewon melalui dialog antar umat beragama yang diprakasai oleh penyuluh agama Islam dan FKUB kecamatan Sewon. Dialog tersebut juga mengajak warga di sekitar gereja Saman baik yang pro maupun kontra. Tanggal 21 Juli untuk sementara plang atau plakat Gereja Baptis Indonesia atau GBI dilepas dan aktifitas gereja pindah di rumah warga. Dialog kedua terjadi kesepakatan karena IMB sudah turun dari Dinas Perijinan Bantul yang dibacakan oleh Kasubag TU Wahib Jamil, S.Ag untuk itu warga di sekitar gereja untuk menghormati hasil kesepakatan.

4. Hasil penyelesaian konflik, hasil penyelesaian konflik antar umat beragama di kecamatan Sewon dapat berlangsung lancar dan 
damai dengan beberapa kesepakatan diantarnya warga masyarakat tetap dapat melalui akses jalan yang diberikan pihak gereja dan gereja mengurangi kegiatan pengobatan gratis dan pembagian sembako. Pihak gereja menyetujui, tetapi untuk sembako tetap diberikan dalam rangka perayaan Natal dibagikan khusus janda yang miskin dan bukan secara umum warga yang miskin.

5. Kondisi Pasca Konflik, menurut Suciati dengan konflik, kita sadar bahwa ada persoalan yang perlu dipecahkan dalam hubungan kita dengan orang lain dan dengan konflik menyebabkan dorongan dalam diri untuk melakukan perubahan. Untuk itu masyarakat Saman Kehidupan keagamaan di Saman sesudah pasca konflik berjalan normal sebagimana disampaikan dukuh Saman yaitu bapak Kuat Salmet yang menyatakan bahwa kehidupan normal. Bahkan di setiap even Natal warga sekitar mendapatkan bantuan sembako dari gereja sedangkan di kegiatan masyarakat seperti gotong royong, rembug desa maupun bersih desa pihak gereja ikut membantu termasuk pendeta Joni Teguh Haryadi. Dengan demikian isu yang mencuat bahwa gereja Saman akan membeli tanah sekitar tidak terbukti bahkan warga di belakang gereja yang melewati jalan milik gereja tetap beraktifitas seperti biasanya. Bahkan jemaat gereja yang bernama Petrus dengan keihlasan mengajarkan gamelan dan tembang kepada warga masyarakat sekitar yang terdiri dari tiga RT atau satu blok. Demikian gambaran keberagaman pasca konflik sampai sekarang.

Kesimpulan dari beberapa wawancara dengan tokoh masyarakat dan humas dan kerukunan umat beragama Ponijo, MA menyampaikan tentang kefanatikan yang berlebihan dari masyarakat beragama dapat memicu konflik baik untuk intern umat beragama misalnya NU dan Muhammadiyah maupun antar umat beragama

\section{Peran Penyuluh Agama Islam Dalam Pencegahan Dan Penyelesaian Konflik Umat Beragama di Kecamatan Sewon Internal Umat Islam}

Peran penyuluh agama Islam dalam pencegahan dan penyelesaian konflik umat beragama dalam internal umat Islam melalui,

a. Ceramah

Penyuluh agama Islam memberikan ceramah mengeani indahnya kebersamaan.Perbedaan khlifiyah yang ada di dalam masyarakat jangan menjadi penghambat bermasyarakat. Ceramah disampaikan di dalam Majelis-majelis Taklim binaan penyuluh yang ada di Kecamatan Sewon. 
b. Dialog

Dialog dengan berbagai ormas Islam, organisasi massa yang besar seperti Muahmmadiyah dan NU selalu dilibatkan dalam dialog bersama dan juga pejabat lintas sektoral. Selain dialog juga diadakan kepengurusan bersama seperti di FKUB maupun Forom Komunikasi Lembaga Dakwah atau FKLD kecamatan Sewon.

\section{Ekternal Umat Beragama}

Peran penyuluh agama Islam dalam pencegahan konflik umat beragama di kecamatan Sewon bagian eksternal umat beragama melalui,

a. Sosialisasi pendirian tempat Ibadah, Penyuluh agama Islam memberikan sosialisasi tempat ibadah baik kepada jamaah umat Islam maupun non muslim. Diharapkan dengan sosialisasi ini dapat mengurangi konflik yang ada karena meningkatnya pemahaman masyarakat. Sosialisasi tersebut penyuluh juga bekerjasama dengan FKUB kecamatan membagi buku sosialasi pendirian tempat ibadah dan SKB pendirian tempat Ibadah.Keberhasilan siosialissai sebenarnya cukup baik terbukti dari tahun 2014 sampai dengan 2016 tidak ada perkembangan pengembangan tempat beribadah, artinya jika tidak sesuai dengan aturan tersebut masyarakat tidak membangun tempat ibadah. b. Dialog, dialog dengan berbagai umat beragama dilakukan bekerjasama dengan pengurus FKUB kecamatan yang disesuaikan dengan dana yang ada. Penyuluh agama Islam sebagai mediator dalam dialog tersebut. Dialog dilakukan dua kali dalam setahun. Dengan dialog tersebut diharapkan dapat menambah erat persaudaraan baik tokoh agama Islam, Kristen, Katholik, Hindu maupun Budha. Dari tokoh tersebut dapat menyampaikan di kalangan pengikut agama dalam masyakarat.

c. Kerjasama, Penyuluh agama Islam di Kecamatan Sewon bekerjasama dengan warga masyarakat yang berkonflik seperti di dukuh Saman mengadakan kegiatan bersama. Kegiatan bersama tersebut seperti lomba 17 Agustus, disini peran penyuluh agama Islam sebagai motivator kepada tokoh agama. Penyuluh agama Islam selain beberapa peran tersebut tidak lupa membuka jejaring masyarakat atau bekerjasama dengan lembaga yang ada. Diantaranya membuat wadah penyuluh di kecamatan Sewon yaitu FOSIPA (Forum Silaturrahim Penyuluh Agama ) kecamatan Sewon.

d. Memberikan ceramah atau dakwah tentang Kerukunan Umat Beragama. Penyuluh memberikan ceramah atau dakwah tentang Kerukunan Umat Beragama dilaksanakan baik antar umat 
beragama.Untuk peran ini penyuluh senantiasa memberikan materi kerukunan umat beragama yang dilakukan rutin 3 bulan sekali untuk mengingatkan kepada masyarakat pentingnya kerukunan umat beragama sebagaimana citacita bangsa Indonesia.

e. Pendampingan jamaah sangat penting terutama dalam penguatan aqidah jamaah, hal ini penyuluh membuat proposal dan mengajukan ke BAZNAS untuk memberikan dana bantuan kepada masyarakat muslim di sekitar gereja. Bantuan berupa sembako, alat-alat usaha mikro seperti gas elpiji bagi pedagang. domba betina bagi peternak, mesin jahit dan lain sebagainya.

f. Pembentukan paguyupan blok yang terdiri dari RT 01, 02 dan 03 yang diketuai oleh bapak Darnawi.

\section{Faktor Pendukung Dan Faktor Penghambat Peran Penyuluh Agama Islam Dalm Pencegahan Dan Penyelesaian Konflik Di Kecamatan Sewon}

1. Faktor Pendukung keberhasilan pencegahan dan penyelesaian konflik umat beragama konflik umat beragama

a. Internal umat Islam diantaranya adalah kesadaran keberagamaan, dukungan dari pemerintah kabupaten Bantul dan lembaga dakwah seperti MUI, DMI, LPTQ , Banyaknya pondok pesantren dan majelis taklim yang menjadi modal dasar membangun masyarakat yang madani sehingga keberagamaan semakin baik. Generasi muda yang masih dapat digerakkan untuk kegiatan social yang diadakan Penyuluh dalam even-even keagamaan dan social seperti MTQ, Lomba Hadroh, Bakti social kerukunan dan lain sebagainya

b. Eksternal antar umat beragama yaitu 1) Kesadaran keberagamaan, bahwa masyarakat apabila menyadari tentang diri yang berbeda-beda dan dapat memahami dari masyarakat yang lain dapat terwujud kerukunan umat beragama. 2) Dukungan pemerintah melalui anggaran yang diberikan melalui FKUB, dengan dukungan dana dapat menyelenggarakan dialog antar umat beragama yang memang membutuhkan dana.

2. Faktor Penghambat peran penyuluh agama Islam dalam pencegahan dan penyelesaian konflik umat beragama di Kecamatan Sewon

a. Internal umat Islam diantaranya 1) fanatik golongan yang berlebihan, Umat Islam terdiri dari beberapa golongan dan organisasi yang besar khusunya di kecamatan Sewon 
adalah

NU

dan

Muhammadiyah.

Dalam

tataran beberapa tokoh agama

baik yang memegang jabatan di organisasi tersebut biasanya hubungan baik-baik saja. Masyarakat bawah atau awam biasnya lebih fanatic sehingga dapat menimbulkan konflik. 2) Perbedaan social ekonomi. Beberapa kejadian konflik awalnya dipicu dari perbedaan social ekonomi yang berimbas kepada konflik agama. 3) Kurangnya dana sebagai modal atau suntikan untuk kegiatan baik yang Muhammadiyah maupun NU. 4) Pendataan peta dakwah,kurangnya pemetaan khususnya daerah rawan konflik sehingga konflik tidak dapat terhindarkan.

c. Eksternal umat beragama, diantaranya 1) Fanatik agama yang berlebihan, Kecamatan Sewon terdiri berbagai macam agama dan golongan. Apabila masing-masing agama mempunyai sifat fanatic yang berlebih maka akan terjadi mudahnya konflik terjadi. Dalam tataran beberapa tokoh agama baik yang memegang jabatan di lembaga seperti FKUB tersebut biasanya hubungan baik-baik saja.Masyarakat bawah atau awam biasnya lebih fanatic sehingga dapat menimbulkan konflik. 2) Kecemburuan social ekonomi, beberapa kejadian konflik awalnya dipicu dari rasa cemburu yang berlebihan di bidang social ekonomi yang berimbas kepada konflik agama. 3) Kurangnya dana sebagai modal atau suntikan untuk kegiatan baik warga masyarakat yang berormas Muhammadiyah maupun NU serta warga non muslim lainnya. 4) Kurangnya pendataan peta dakwah , Kurangnya pemetaan khususnya daerah rawan konflik yang hendaknya dilakukan oleh penyuluh agama Islam sehingga konflik tidak dapat terhindarkan.

\section{KESIMPULAN}

Kesimpulan dari penelitian peran penyuluh agama Islam dalam pencegahan dan penyelesaian konflik di Kecamatan Sewon yaitu,

1. Konflik yang ada di Kecamatan Sewon

a. Konflik pemahaman masyarakat anatara NU dan Muhammadiyah di Timbulharjo

b. Konflik tempat peribadatan di Dongkelan Panggungharjo Sewon

c. Konflik Gereja St Martinus di Gandok Bangunharjo Sewon

d. Konflik Gereja Kristen Baptis di Saman Bangunharjo Sewon

2. Peran Penyuluh Agama Islam dalam Pencegahan dan 
penyelesaian konflik umat beragama di Kecamatan Sewon

a. Internal umat Islam, diantaranya dengan 1) Ceramah, untuk menguatkan masing-masing jamaah agar tidak mudah terprovokasi senantiasa memberikan ceramah terutama tiga kerukunan kepada jamaah. 2) Dialog, hal ini dilakukan terutama saat menjelang puasa ramadhan dan bulan syawal agar tidak terjadi konflik dan saling memahami perbedaan

b. Ekstern umat beragama yaitu 1) Sosialisasi pendirian tempat ibadah, hal ini dilakukan dalam di awal tahun kepenyuluhan agar warga menjadi lebih paham tentang pendirian tempat ibadah dan tidak menimbulkan konflik, 2) Dialog antar umat beragama, hal ini dilakukan bersamasama dengan pengurus FKUB kecamatan Sewon dan lintas sektoral disesuaikan dengan anggaran yang ada dan situasi yang urgen, 3) Kerjasama, dilakukan dalam bentuk kegiatan bersama seperti outbond lintas agama yang dananya dari FKUB Bantul dan menggelar wayang, 4) Ceramah kepada jemaat masing-masing pentingnya kerukunan umat beragama, hal ini dilakukan melalui majelis taklim binaan penyuluh yang berjumlah 160 dan belum terjangkau semuanya, 5) Pendampingan jamaah dilakukan dalam rangka penguatan aqidah. Penyuluh mengajukan proposal ke BAZNAS Kabupaten Bantul dan mengadakan bakti social dalam masyarakat. 6) Pembentukan paguyupan blok dari RT 01, RT 02 dan RT 03 dengan pimpinan bapak Darnawi.

\section{SARAN}

Saran-saran untuk beberapa instansi terkait

1. Kementerian Agama Kabupaten Bantul, dalam mengambil rekrutmen pegawai hendaklah disesuaikan dengan kualitas keilmuan seperti penyuluh adalah lulusan dakwah dan sebagainya bukan diambil dari K2 yang lulusan SMP, SMA bahkan ada yang SD dan usia yang kurang produktif. Kemenag dapat memberikan silabus tentang kerukunan umat beragama kepada penyuluh sehingga dapat memberikan kepada jamaah dengan tepat dan efektif.

2. FKUB dan lembaga dakwah terkait, hendaklah bisa senantiasa ditingkatkan jejaring social di kecamatan masing-masing, karena selama ini lembaga dakwah berjalan apabila ada kucuran dana sehingga ketika terjadi masalah kemudian menjadi terkesan 
terburu-buru dalam mengambil sebuah keputusan.

3. Pihak UMY, hendaklah dapat bekerjasama dengan Kementerian Agama dalam beberapa hal khusunya tentang kerukunan umat beragama dan peta dakwah.

\section{DAFTAR PUSTAKA}

Arifinsyah. 2011. Peran FKUB Dalam Penyelesaian Konflik Di Propinsi Sumatera Utara. Jurnal Harmoni Jan-Maret 2011. Murtikultural dan Multirelegius. Volume X.

Am Romly. 2001. Penyuluhan Agama Dalam Menghadapi Tantangan Baru. Jakarta : Bina Rena Pariwara.

Aparatur Negara Nomor: 54/KEP/MK.WASPAN/9/1999 tentang Jabatan Fungsional Penyuluh Agama dan Angka Kreditnya.

Hendri Bakri. 2011. Resolusi Konflik melalui pendekatan kearifan local Pela Gandong di Kota Ambon. Jurnal Magister Ilmu Politik Hasanuddin. Volume 1.nomor 1. Januari 2011.

Agus Burhanudin. 2010. Agama dan Pengelompokan Sosial. Jakarta: UI Press.

Departemen Agama. 2006. Al Qur'an dan Terjemahannya. Bandung : CV Penerbit Diponegoro.

Ibrahim, Jabal Tarik, Arman Sudijono dan Harpowo. 2003. Komunikasi dan penyuluhan pertanian.
Malang : Banyumedia

Publishing. UMM Press.

Nawari Ismail. 2011. Konflik Umat Beragama dan Budaya Lokal. Bandung: Lubuk Agung.

2014. Relasi Islam Sempalan, Islam Mapan dan Nagara. Yogyakarta: Penerbit Samudra Biru.

Kamus Besar Bahasa Indonesia, 2008. Pusat Bahasa Indonesia edisi keempat Depatemen Pendidikan Nasonal. Jakarta : Gramedia Pustaka Utama. cetakan I edisi IV.

Kementerian Agama Kabupaten Bantul. 2015. Kumpulan Peraturan Pendirian Rumah Ibadah di Kabupaten Bantul.

Kantor Wilayah Kementerian Agama. 2015. Kumpulan Peraturan Perundang-undangan Kerukunan Umat Beragama.

Khilmiyah, Akif. 2016. Metode Penelitian Kualitatif. Yogyakarta : Samudra Biru.

Koeswinarno dan Fakhrudin. 2013. Persepsi Penyuluh Agama tentang Konflik Berbasis Agama (kasus Ahmadiyah dan Tijani di Kabupaten Sukabumi). Jurnal Harmoni Mei-Agustus.

Muhibuddin Wijaya Laksana. 2015. Psikologi Komunikasi. Bandung: CV Pustaka Setia

M. Lutfi. 2008. Dasar-dasar Bimbingan dan Penyuluhan 
(konseling) Islam. Jakarta: Lembaga Penelitian UIN Syarif Hidayatullah.

Mihaela, Nita Andre and Cristina, Illie Gogi. 2015. A Research in the educational counseling and carrerguidance in Rumania 2015. European Scintific Jounal Februari. 2015/Spicial/edition Vol.2 ISSN : 1857-7881 e ISSN : 1857-7431.

Siti Mutmainnah. 2014. Peran Dakwah Dalam Mengatasi Konflik Social Masa Kini. Jurnal Dakwah Tabligh. Vol.15 No.2. Desember 2014.

M. Yunus, Firdaus. 2014. Konflik Agama di Indonesia Problem dan solusi Pemecahannya. Jurnal Substantia. Volume 16 Nomor 2 Oktober 2014

Raharjo Jati, Wasisto. 2013. Kearifan lokal sebagai Resolusi Konflik. Jurnal Walisongo. Volume 21. Nomor 2.November 2013.

Qomariyah, Puji Tim LBB Scintersolusi, 2008. Teori Ringkas Latihan Soal dan pembahasan Sosiologi. Yogyakarta : Pustaka Pelajar

Rizqiawaty, Nova, 2011. Sosiologi Agama. Jakarta : Kencana Mas.

Soekanto, Soerjono, 1990. Sosiologi Suatu Pengantar. Jakarta: PT Raja Grafindo Persada. 1986. Sosilogi Suatu Pengantar. Jakarta : Rajawali Press.
, 1982. Memperkenalkan

Sosiologi. Jakarta : CV Rajawali

Bachtiar Wardi, 1997. Metodologi Peneltian Ilmu Dakwah. Jakarta: Logos 